\title{
Active Methylene Phosphinic Peptides: A New Diversification Approach
}

\author{
Supporting Information
}

\section{HPLC Chromatograms}

Magdalini Matziari, Magdalini Nasopoulou and Athanasios Yiotakis

University of Athens, Department of Chemistry, Laboratory of Organic Chemistry, Panepistimiopolis Zografou 15771, Athens, Greece 
mAU

3000

2500

2000

1500

1000

500

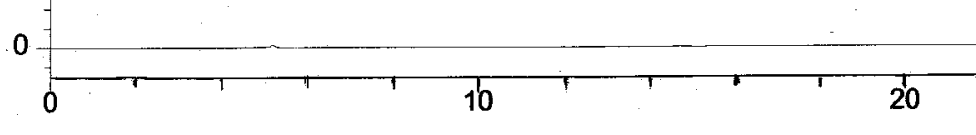

$4 b$

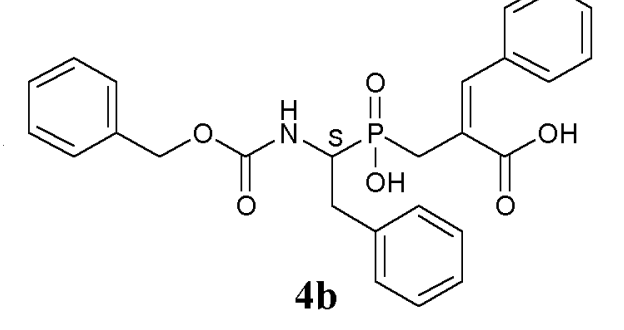

35.90 
mAU

300

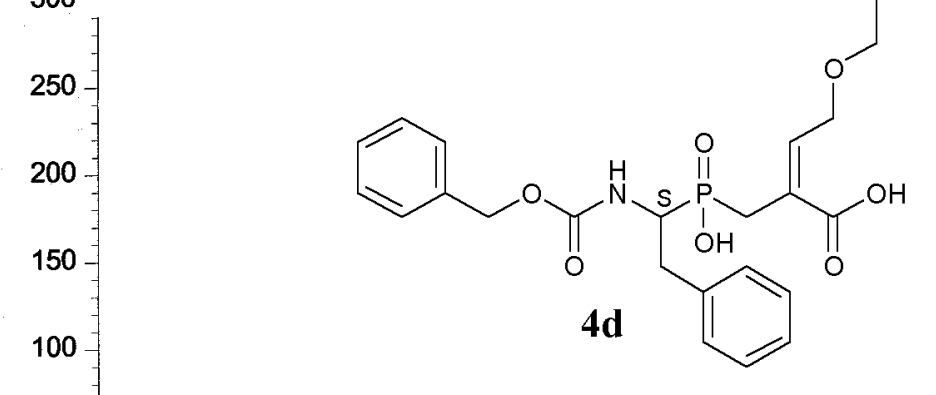

36.30

37.70

S5

50

10

h 


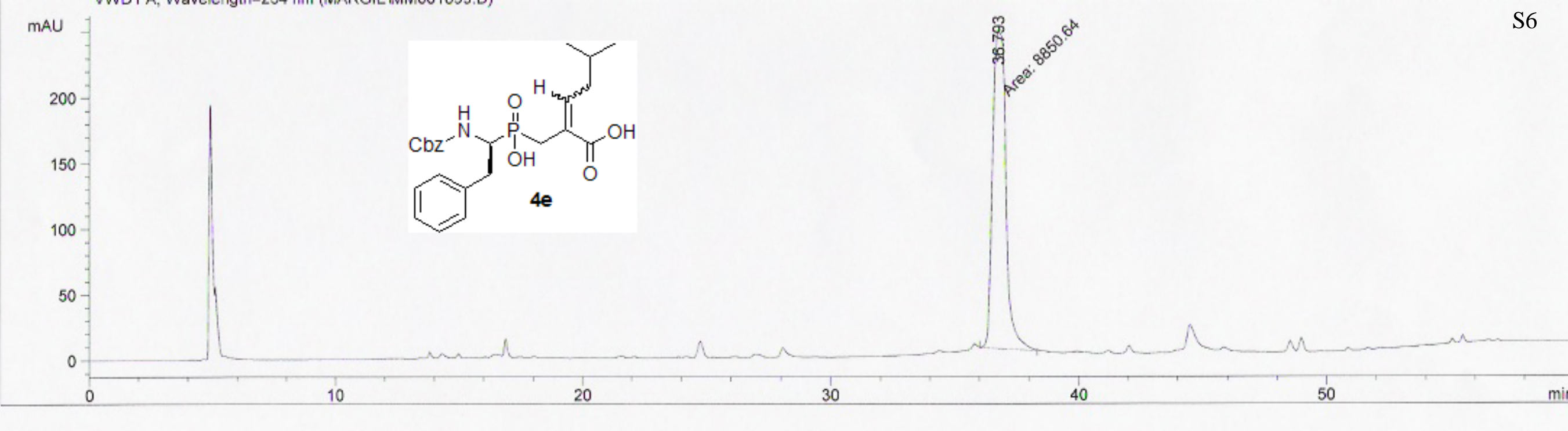




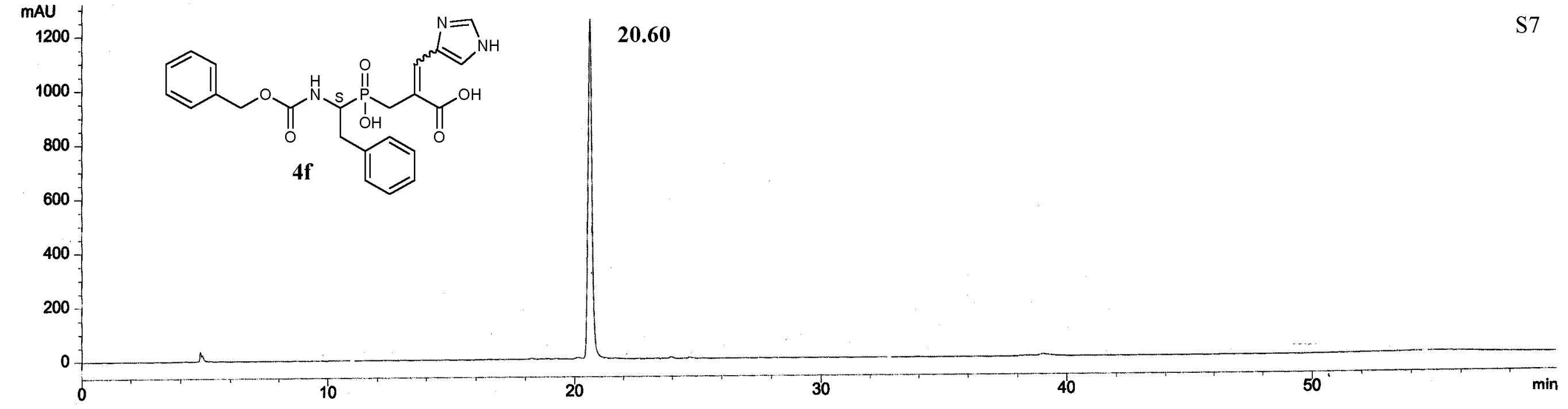




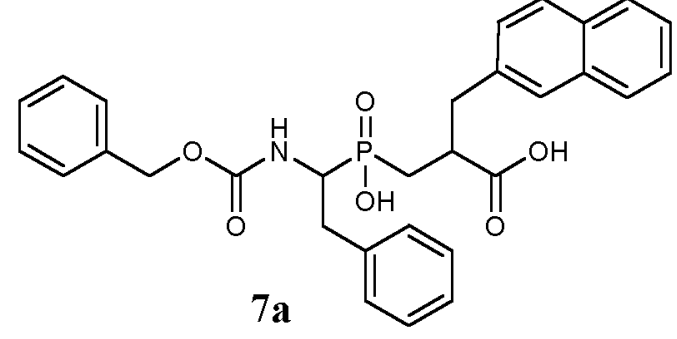




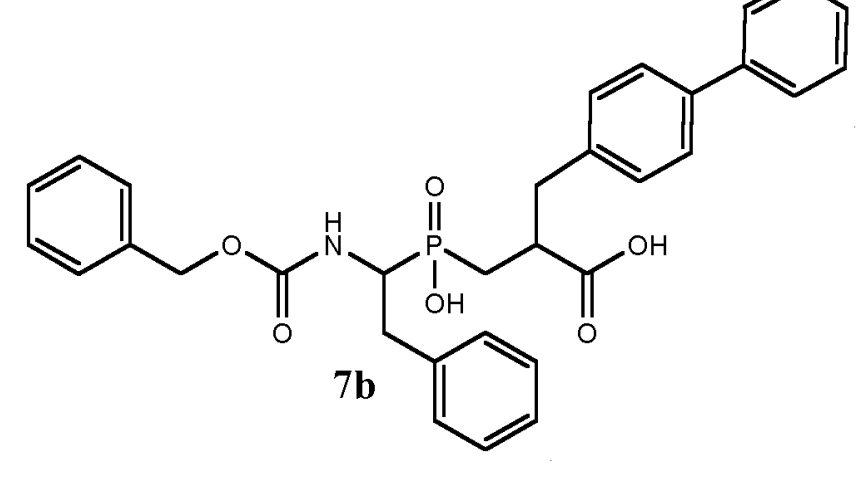

